Florida International University FIU Digital Commons

\title{
The (Wo)Man in the Masque: Cross-Dressing as Disguise in Early Modern English Literature
}

Chelsea E. Franco

cfran020@fiu.edu

DOI: $10.25148 /$ etd.FI15032170

Follow this and additional works at: https://digitalcommons.fiu.edu/etd

Part of the Literature in English, British Isles Commons

\section{Recommended Citation}

Franco, Chelsea E., "The (Wo)Man in the Masque: Cross-Dressing as Disguise in Early Modern English Literature" (2015). FIU Electronic Theses and Dissertations. 1780.

https://digitalcommons.fiu.edu/etd/1780 


\title{
FLORIDA INTERNATIONAL UNIVERSITY \\ Miami, Florida
}

THE (WO)MAN IN THE MASQUE:

CROSS-DRESSING AS DISGUISE IN EARLY MODERN ENGLISH LITERATURE

\author{
A thesis submitted in partial fulfillment of the \\ requirements for the degree of \\ MASTER OF ARTS \\ in \\ ENGLISH \\ by
}

Chelsea Elena Franco

2015 
To: $\quad$ Dean Michael R. Heithaus

College of Arts and Sciences

This thesis, written by Chelsea Elena Franco, and entitled The (Wo)Man in the Masque: Cross-Dressing as Disguise in Early Modern English Literature, having been approved in respect to style and intellectual content, is referred to you for judgment.

We have read this thesis and recommend that it be approved.

Jason H. Pearl

Andrew Strycharski

Heather E. Blatt, Major Professor

Date of Defense: March 26, 2015

The Thesis of Chelsea Elena Franco is approved.

\begin{tabular}{r} 
Dean Michael R. Heithaus \\
College of Arts and Sciences \\
\hline Dean Lakshmi N. Reddi \\
University Graduate School
\end{tabular}

Florida International University, 2015 


\section{ACKNOWLEDGMENTS}

Thank you to my Imma, Dad, and the rest of my family for having always facilitated and encouraged my academic and intellectual pursuits, whether herpetological, musical, or literary. I would not be who I am today without your love and support.

I could not have completed this project nearly as efficiently without my friends. Cayce, thank you for helping put my thoughts into words and for proofreading my early drafts. Carla, thank you for everything you helped me do over the course of this project. Your patience with me and faith in my abilities aided my quest to complete this thesis more than you could possibly imagine.

I would like to thank the FIU English Department for being an incredible learning environment and fostering my love of literature. James Sutton, thank you for the idea to compare Sidney to Cavendish for my thesis. Your support and feedback have been a valuable asset to my education.

To my phenomenal thesis committee, thank you for your support and dedication over the course of this project. Jason Pearl, thank you for your prompt, thoughtful feedback and for always being available to answer my questions. Andrew Strycharski, thank you for being my introduction to Sidney and for making me love Renaissance literature more than I ever thought I could. Studying with you these past five years has been an invaluable experience and immense privilege. Last, but certainly not least, Heather Blatt, thank you for your patience and guidance and for taking on the role of Head of Committee with such aplomb. Your organization and ability to ask questions I had never thought of being able to answer set me on the right track for this project and aided my writing process not only for this thesis but for my writing in general. 


\begin{abstract}
OF THE THESIS
THE (WO)MAN IN THE MASQUE:

CROSS-DRESSING AS DISGUISE IN EARLY MODERN ENGLISH LITERATURE

by
\end{abstract}

Chelsea Elena Franco

Florida International University, 2015

Miami, Florida

Professor Heather E. Blatt, Major Professor

Characters' identities are integral to how audiences relate to them. But what happens when the character suddenly alters his or her outward appearance? Are they still the same person? This thesis seeks to argue that disguise does not alter a character's true nature, as evidenced by Pyrocles in Sir Philip Sidney’s “The Countess of Pembroke’s Arcadia” and the Prince in Margaret Cavendish’s “The Convent of Pleasure.” Both Pyrocles’ suit of Philoclea and the Prince’s suit of Lady Happy are successful because, however subversive they appear at first, they ultimately adhere to societal norms of the time. The relationship between the cross-dressed prince and his love interest in both works only appears to subvert heteronormative expectations for the time, but ultimately adheres to these societal norms once the disguised character's true identity is revealed to his chosen partner. 


\section{TABLE OF CONTENTS}

CHAPTER

PAGE

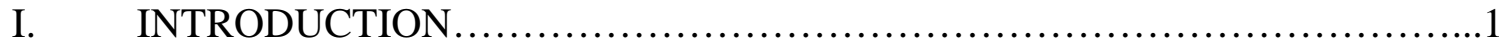

II. BE CAREFUL WHAT YOU WISH FOR:

PYROCLES AND THE EROTICIZATION OF THE “FEMALE” FORM........15

III. THE PRINCE(SS) AND THE PLAYS (WITHIN THE PLAY) ..................37

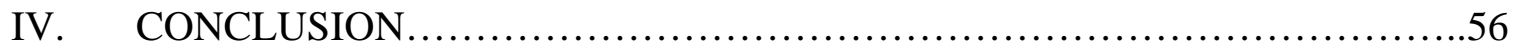

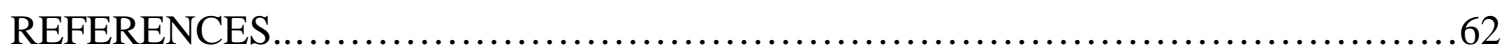




\section{INTRODUCTION}

Characters' identities are integral to how audiences relate to them. But what if the character suddenly alters this identity? Are they still the same person? The use of disguise as the means for a character to achieve his or her goals is quite common in literature, especially in early modern England (circa sixteenth to eighteenth century). However, it appears that these works cross class lines more often than the boundaries which differentiate what is considered "male" from what is considered "female" for that time. Sir Philip Sidney and Margaret Cavendish, Duchess of Newcastle, both use maleto-female cross-dressing in their New Arcadia and Convent of Pleasure, respectively. These works both feature a prince who decides that the only way for him to woo his desired female counterpart is to cross-dress and infiltrate her secluded home, where she has been isolated.

For purposes of this thesis, the term "cross-dressing” is defined as the action of intentionally deceiving others regarding one's gender. While this term does specifically refer to what the cross-dresser wears, it can also apply to other modifications of the subject's appearance, as in the case of Pyrocles styling his hair in a "feminine" manner for the sake of his performance as Zelmane, as well as the adoption of mannerisms typically attributed to the opposite gender and the imitation of a different vocal range. While gender can be seen as a mode of performance, the term “drag” does not apply to this thesis, as drag performers imitate the opposite gender in a dramatic and obvious fashion, their true sex generally unmistakable to those around them. The term “transvestism” likewise cannot be applied herein because of its typically fetishistic connotations. 
Cross-dressing is, of course, not unique to these works, or even to early modern England. Instances of cross-dressing can be found in works such as Le Roman de Silence, an Old French text about the only child of a noble family raised as a boy because women were not allowed to inherit property. William Shakespeare, possibly one of the most famous authors of the early modern era in England, wrote several plays involving cross-dressing, though most seem to be of the female-to-male variety. Shakespeare is especially important herein because he was influenced by Sir Philip Sidney, as well as being an influence on Margaret Cavendish. Sidney even uses cross-dressing elsewhere in the New Arcadia: Zelmane, the woman from whom Prince Pyrocles gets his "female" name, disguises herself as a page named Daiphantus in order to stay close to the prince, only revealing her true identity on her death bed.

Sir Philip Sidney's The Countess of Pembroke's Arcadia (also known as The New Arcadia) is the revision of what is now referred to as Sidney's Old Arcadia. Although Sidney died before completing The New Arcadia, it is the more well-known version of the story. Several continuations of The New Arcadia exist, but for this thesis, the continuation written by Sir William Alexander in the early seventeenth century will be used. The New Arcadia contains the stories of several characters, one of whom is Prince Pyrocles of Macedon, who falls in love with Princess Philoclea. Philoclea has been isolated in the Arcadian Forest as a result of a prophesy given to her father by the Oracle at Delphos, and, in order to gain her favor, he must first be able to access her secluded home and convince her of his suit, a feat which would be impossible for him as a male of a social class appropriate to Philoclea's station. Therefore, he devises a plan to seduce her by dressing as a woman—specifically the Amazon Zelmane—and infiltrating her 
secluded home, living with her and her parents. Unfortunately for Pyrocles, the requirement that he woo Philoclea whilst avoiding the affections of her parents, both of whom are madly in lust with him, complicates this quest.

The Convent of Pleasure is a short play about a woman (Lady Happy) who inherits her deceased father's fortune. She decides to establish a convent for unmarried maidens and widows to help those who do not wish to conform to societal standards and suffer the woes presumed to be associated with marriage. Because Lady Happy is "extream handsome, young, rich, and virtuous," she is very much desired as a commodity (not so much as a wife- the concept of love does not come up until much later in the play). ${ }^{1}$ Lady Happy has several suitors, one of whom, Monsieur Take-Pleasure, proposes cross-dressing as a means of gaining entry into the Convent, but his companions dismiss this idea. A Prince, presumably younger than Take-Pleasure and his cohort, learns of this Convent wherein all the virtuous maids hide, and disguises himself as a princess "of Masculine Presence” in order to gain entrance, after which point he seduces Lady Happy and ultimately marries her offstage once he discloses his true identity. ${ }^{2}$

In Book 2, Chapter 7 of The New Arcadia, Sir Philip Sidney reveals that Pyrocles is approximately seventeen years of age, as he had started his journey around the world which ended in shipwreck at sixteen and the events which take place in The New Arcadia occur between six months and a year after this episode. ${ }^{3}$ His age relates to that of the

1. Margaret Cavendish, The Convent of Pleasure, ed. Anne Shaver (Baltimore, MD: The Johns Hopkins University Press, 1999), Act I Scene 1.

2. Cavendish, The Convent of Pleasure, Act II Scene 3.

3. Sir Philip Sidney, The Countess of Pembroke's Arcadia (New York, NY: Penguin Classics, 1987), 259-260. 
typical boy actor on the stages of the time period. According to Mary Bly’s Queer Virgins and Virgin Queans, boy actors would have been on average between the ages of fourteen and seventeen, at which point they would have been able to both memorize their lines and still have the high voices required to pass as women. Bly also states that boy actors would grow their hair long, as evidenced by the various works from that time which eroticize the long, flowing tresses possessed by these young men. Sidney, too, emphasizes the erotic nature of long hair. When Musidorus first stumbles upon Zelmane in a clearing in the Arcadian forest, for instance, he describes at length her long, beautiful hair before hearing her voice and recognizing her as actually being his cousin Pyrocles. ${ }^{4}$

While Cavendish is not explicit about any of the Prince's defining physical characteristics or about his age, she does include a character who, similar to Musidorus, seems to be too old to cross-dress effectively. That character is Monsieur Take-Pleasure, who with his companions discusses cross-dressing as a means of gaining entry into the Convent and thereby getting access to the women "incloistered" therein, but ultimately dismisses this idea as illogical, especially given the tones of their voices. This discussion between Take-Pleasure and his cohort can be seen as a play on Pyrocles/the Prince's use of cross-dressing as a means of penetrating the defenses of their respective love interests' secluded homes. It can also be viewed as comment about the ages of Monsieur TakePleasure, his companions, and the Prince (who is ultimately successful in his disguise and subsequent bypassing of the defenses of both the Convent and of Lady Happy herself).

4. Sidney, The Countess of Pembroke's Arcadia, 130. 
Pyrocles and the Prince are ultimately successful in their respective plots to seduce and secure the affections of their chosen mates because both of their suits adhere to accepted societal norms of the time. Not only are the matches "good" because they occur between a man and a virtuous (chaste) maiden, but both parties are also of a similar social standing, ensuring that, once their respective marriages occur, they fall firmly within the early modern audience's expectations regarding suitable pairings. The New Arcadia contrasts this "good” suit with several nonsensical ones, such as Basilius' suit of Zelmane, which cannot succeed because both parties are male (though Basilius is ignorant of this for the vast majority of the work). Zelmane sidesteps the king's advances several times, clearly uninterested in him and disgusted by his bumbling displays of affection.

The two cross-dressed men seem to be excellent at performing as the opposite gender, as they achieve their goals of wooing their respective loves before their true selves are revealed, causing much distress and confusion on the parts of Philoclea and Lady Happy (as well as the people around them) in the process. Both of these performances are aided not only by the characters' ages, but also by their performance as a woman "of Masculine Presence." Despite having seen these men in clothing considered more appropriate for their natural sex, most of the characters in both The Convent of Pleasure and The New Arcadia are still easily deceived into thinking that the Princess and Zelmane (respectively) are actually female.

5. Cavendish, The Convent of Pleasure, Act II Scene 3. 
According to Thomas Laquer's Making Sex: Body and Gender from the Greeks to Freud, it was generally accepted during the early modern era that there was no biological differentiation between "male” and "female," only a notion that the female form was a less perfect version of her male counterpart's, her "penis" turned inside-out to create her womb. In early modern England, similar to today's society, people would use the way in which an encountered individual accoutered his- or herself to ascertain their sex:

"When you meet a human being," said Freud in his comments on "Femininity" in New Introductory Lectures, "the first distinction you make is 'male or female?' and you are accustomed to making the distinction with unhesitating certainty." Anatomical science at first seems to support this certainty but upon further reflections turns out to be far less authoritative: "what constitutes masculinity or femininity is an unknown characteristic anatomy cannot lay hold of.” The more Renaissance anatomists dissected, looked into, and visually represented the female body, the more powerfully and convincingly they saw it to be a version of the male's. [...] Indeed, in the absence of a purportedly stable system of two sexes, strict sumptuary laws of the body attempted to stabilize gender-woman as woman and man as man—and punishments for transgression were quite severe. ${ }^{6}$

Cross-dressing, the intentional subversion of these sumptuary laws, was controversial at best, even when applied to boy actors in the theater. If performing as the opposite gender had such severe consequences, why would Pyrocles and the Prince have gone to these lengths to secure a spouse? Surely there were other maidens the pursuit of whom did not require such perils. These works both show not only the trials a romantic protagonist is willing to endure in order to obtain his love's favor (though these lengths are viewed in a critical fashion in The Convent of Pleasure), but also the opinions on appropriate marriages espoused by society in early modern England. Because Pyrocles and the Prince are successful in their respective suits, Sidney and Cavendish show that,

6. Thomas Laquer, Making Sex: Body and Gender from the Greeks to Freud (Cambridge, MA: Harvard University Press, 1990), 70, 124. 
ultimately, a suit which adheres to societal norms regarding gender and social class is acceptable. Musidorus’ need to “counterfeit” his suit of Dametas’ daughter Mopsa because he cannot approach his own love interest with his suit given that he is disguised as a shepherd and she is a princess provides further evidence of the societal need for partners to be of a similar social class.

The two princes' female counterparts both wish that the woman to whom they are attracted was really a man so that they might be able to marry, not realizing that Zelmane and the Princess actually are men until later. Although Zelmane dresses as a knight in order to defend Philoclea's beauty, Philoclea is still fully convinced that Zelmane is a woman. Unlike Lady Happy, she accepts her love for Zelmane before finding out that her love is really Prince Pyrocles. When Philoclea does find out, she decides that she will still refer to him as Zelmane, "since in that name [her] love first began.”7 Lady Happy, on the other hand, refuses to let herself accept her love for the Princess until she discovers her true identity. She does, however, admit her attraction to the woman serving her, despite their differences of opinion regarding the institution of marriage, to which Lady Happy is vehemently against throughout most of the play. Even though both of these maidens find themselves falling in love with another woman, neither acts upon these feelings until her cross-dressed counterpart reveals that accepting them does, in fact, constitute a relationship "suitable” to her gender and station.

It might be expected that, even if the two princes do pass as women, they would not be especially attractive, as female is not their "natural" state. However, not only do

7. Sidney, The Countess of Pembroke’s Arcadia, 330. 
Zelmane and the Princess gain the favor of the women they wish to seduce, they seem to attract the attention of the other characters around them, as well. Pyrocles in particular is such an attractive woman that he has to constantly fend off the advances of King Basilius and his wife Gynecia (Philoclea’s parents) and even manages briefly to fool his cousin Musidorus, who thinks "her” a stunningly gorgeous woman until he hears Pyrocles' voice. No one suspects that the Princess was in disguise a man until Madam Mediator sees his female persona kissing Lady Happy "with more alacrity then Women use, a kind of Titillation, and more Vigorous." ${ }^{8}$ Even then, she does not reveal her suspicions so as not to appear jealous of the Princess and Lady Happy's affections for one another.

Neither Pyrocles nor the Prince disguise themselves as princesses of their own countries, choosing instead to claim to be from places where the women would be thought of as more "masculine”: Pyrocles as an Amazon and the Prince as “a great foreign princess [...] of Masculine Presence.”99 This choice on their parts not only aids their performance as women by explaining any masculine features they may have, but also accounts for anything the men do that might accidentally reveal themselves, such as Zelmane drawing her sword on Dametas upon first meeting the comically idiotic shepherd servant of Basilius, who immediately panics and runs to fetch his Master.

When Pyrocles-as-Zelmane first encounters King Basilius in the Arcadian Forest, s/he gives the king her fabricated history and lineage:

Mighty prince [...] let my not knowing you serve for the excuse of my boldness; and the little reverence I do you, impute it to the manner of my country, which is the invincible land of the Amazons: myself niece to Senicia, queen thereof,

8. Cavendish, The Convent of Pleasure, Act V Scene 2.

9. Cavendish, The Convent of Pleasure, Act II Scene 3. 
lineally descended of the famous Penthesilea slain by the bloody hand of Pyrrhus. I, having in this my youth determined to make the world see the Amazons' excellencies as well in private as in public virtue, have passed some dangerous adventures in divers countries till the unmerciful sea deprived me of my company; so that shipwreck casting me not far hence, uncertain wandering brought me to this place. ${ }^{10}$

Providing a lineage such as that of the mythical Amazon would suit a character such as

Zelmane or the Princess well because both are still male and therefore would presumably

have trouble performing as a woman of a nationality seen as being more delicate:

In Greek mythology, [the Amazons were] tribal female warriors who lived in Cappadocia in Asia Minor. They had only one breast, one having been removed in youth so that they could more freely shoot their bows. No men were allowed in the tribe. Mating took place at certain seasons with men of another race, and only girl babies were kept. If boys were born, they were killed, maimed, or given to their fathers. The Amazons appear in myths relating to Bellerophon, Heracles, Perseus, and Theseus, all of whom fought against them. Theseus kidnaps the Amazon queen Hippolyte (Antiope). Another Amazon queen, Penthesilea, aided the Trojans and was killed by Achilles during the Trojan War. In Greek art the Amazons are portrayed as manly women with two breasts. Usually they are portrayed on horseback sometimes in Scythian dress-a tight tunic with a cloak and a kind of Phrygian cap-though sometimes they are portrayed wearing a Dorian tunic tucked up, the right side bare [...] One Spanish clergyman described them as "very tall, robust, with long hair twisted over their heads, skins around their loins and bows and arrows in their hands, with which they killed seven or eight Spaniards. ${ }^{11}$

This inherent "maleness" associated with the Amazons would likely have been what appealed to Pyrocles in his quest for an appropriate female disguise. Though the Princess does not have an explicitly apparent lineage, Madam Mediator describes her as "a great

10. Sidney, The Countess of Pembroke's Arcadia, 145.

11. “Amazons,” Anthony S. Mercatante and James R. Dow, The Facts on File Encyclopedia of World Mythology and Legend, Third Edition (New York, NY: Facts on File, Inc., 2009), 60-61. 
Foreign Princess [...] a Princely brave Woman truly, of a Masculine Presence." ${ }^{, 2}$ While this description (essentially the only description of the Princess in the entire play) denies the Princess a specific nationality, when combined with several references which point to the characters belonging to a religion based in the Greco-Roman tradition, it implies that the Princess provides Lady Happy, Madam Mediator, and the rest of the Convent's occupants with a similar lineage to that provided by Pyrocles/Zelmane upon first meeting Basilius.

Margaret Cavendish always stated that her words were entirely her own, with nothing taken from outside sources. However, according Mikhail Bakhtin, this is not possible:

This is why the unique speech experience of each individual is shaped and developed in continuous and constant interaction with others' individual utterances. This experience can be characterized to some degree as the process of assimilation--more or less creative--of others' words (and not the words of a language). Our speech, that is, all our utterances (including our creative works), is filled with others' words, varying degrees of otherness or varying degrees of "our-own-ness" ....These words of others carry with them their own expression, their own evaluative tone, which we assimilate, rework, and re-accentuate. ${ }^{13}$

In other words, everything we say (or write) was synthesized from that which we have heard or read throughout our lifetimes, making it impossible for anyone to generate a truly “unique” utterance. Given this “impossibility”; William Cavendish’s influence on his wife's work, particularly The Convent of Pleasure, of which he wrote at least part of the ending; Sir Philip Sidney’s prevalence in literary circles, including ones in which Cavendish was likely to participate; and Sidney's influence on literature from the time of

12. Cavendish, The Convent of Pleasure, Act II Scene 3.

13. Mikhail Bakhtin, Speech Genres and Other Late Essays, Trans. Vern W. McGee (Austin, TX: University of Texas Press, 1986), 89. 
his death through Margaret Cavendish's lifetime and beyond, it can be reasonably deduced that The Convent of Pleasure parodies The New Arcadia, whether or not this parody was intentional on Cavendish's part.

But why compare Sir Philip Sidney and Margaret Cavendish? There exists little, if any, scholarship which puts the two in conversation with one another. This oversight can be explained, at least in part, by a lack of serious academic work on Cavendish in general, as literary scholars did not see her as anything other than "Mad Madge" until the middle of the twentieth century. A very brief conversation between the two authors takes place when Stephen Hequembourg uses Sidney's The Defence of Poetry in his article "The Poetics of Materialism in Cavendish and Milton” as part of his theoretical analysis of Cavendish's works as they relate to Milton's, but does not actually situate her in relation to Sidney as an influential literary figure. Additionally, Amy Greenstadt’s Rape and the Rise of the Author: Gendering Intention in Early Modern England has a chapter on both Sidney and Cavendish, but does not put them together. Others, such as Anne Shaver, compare Margaret Cavendish to Lady Mary Wroth, Sidney’s niece, from whom the Duchess made multiple, vocal attempts at distancing herself, given the controversial nature of Wroth's life and writings. Nevertheless, it seems as though an actual comparison of the works of these two authors does not appear in scholarly works.

Despite this lack of scholarly conversation, Sir Philip Sidney and Margaret Cavendish do approach their respective cross-dressing princes in similar fashions. Scholarly work on these approaches, however, could not be more different, at least partially because Sidney is male and Cavendish is female. Those writing on Sidney's use of cross-dressing in The New Arcadia seem to focus on the social implications of 
Pyrocles’ cross-dressing. For instance, Winfried Schleiner’s article “Male CrossDressing and Transvestism in Renaissance Romances" questions "whether or in what respect [romances which feature cross-dressed males] fulfill the modern psychologist's narrow and not unproblematic definition of male transvestism,” while Mary Ellen Lamb reflects on the "social validity" of Pyrocles' disguise, referring to it as a "gendered act" rendering Pyrocles effeminate because of his "passionate excess" in his suit of Philoclea in her article "Exhibiting Class and Displaying the Body in Sidney's The Countess of Pembroke's Arcadia."

On the other hand, those scholars writing on Margaret Cavendish focus on issues of religion and femininity. Horacio Sierra’s “Convents as Feminist Utopias” argues that The Convent of Pleasure uses the convent as a setting to establish "an idealistic feminine community" to upset Puritans and Protestants, then subverted this community's ideals in order to upset the Catholic Church. In her article "Performance, Performativity, and Identity in Margaret Cavendish’s Convent of Pleasure,” Katherine R. Kellett uses Judith Butler's work on gender to portray the convent which gives the play its title as a means of subverting both heteronormative and non-heteronormative depictions of gender, using language to evolve the bodies portrayed therein. Unlike the works mentioned above, this thesis seeks to argue that the relationship between the cross-dressed prince and his love interest in both works only appears to subvert heteronormative expectations for the time,

14. Winfried Schleiner, "Male Cross-Dressing and Transvestism in Renaissance Romances,” The Sixteenth Century Journal, 19.4 (1988), 607.

15. Mary Ellen Lamb, "Exhibiting Class and Displaying the Body in Sidney's The Countess of Pembroke's Arcadia," Studies in English Literature, 1500-1900, 37.1 (1997), 56. 
but ultimately adheres to these societal norms once the disguised character reveals his true identity to his desired partner.

Although scholarship on The New Arcadia and The Convent of Pleasure focuses on different aspects of the works, establishing that a relationship between the two does exist is not unreasonable. According to Mad Madge: The Extraordinary Life of Margaret Cavendish, Duchess of Newcastle, the First Woman to Live by Her Pen, Margaret Cavendish was familiar with romances (such as The New Arcadia) from having read them with her sisters. She condemned these works later in her life for what she saw as unrealistic portrayals of women and marriage, concerned that these works were damaging to the lives of those who read them. It is possible, therefore, that The Convent of Pleasure, one of her later plays, is a response to the romance genre in general or, specifically, to this story contained within The New Arcadia, created by Cavendish to respond to and parody what she personally viewed as unrealistic. As pertaining to this thesis, the term "parody" is defined as the interpretation of a work of literature (or portion thereof, as the case may be) in a satiric fashion as a means of expressing ridicule of the original work. While the term "burlesque" ("Of the nature of derisive imitation; ironically bombastic, mock-heroic or mock-pathetic; now chiefly said of literary or oratorical compositions and dramatic representations") might also apply here, it does not seem to have come into use until after The Convent of Pleasure was written. ${ }^{16}$ Given the popularity of The New Arcadia during Margaret Cavendish's lifetime, her disdain for romances, her immense respect for William Shakespeare (who was known to draw

16. “burlesque, adj. and n.,” OED Online, September 2014, Oxford University Press, http://www.oed.com/view/Entry/24999 (accessed 16 September 2014). 
inspiration from Sir Philip Sidney), and her penchant for satire, it is entirely feasible that The Convent of Pleasure is a retelling of the tale of Prince Pyrocles in parodic form. 


\section{BE CAREFUL WHAT YOU WISH FOR:}

\section{PYROCLES AND THE EROTICIZATION OF THE “FEMALE” FORM}

"Neither doubt you because I wear a woman’s apparel I will be the more womanish, since I assure you, for all my apparel, there is nothing I desire more than fully to prove myself a man in this enterprise." ${ }^{, 17}$ Pyrocles, Prince of Macedon, speaks this line to his cousin Musidorus, who had just accused him of becoming woman-like because he is dressed as a woman. Pyrocles outfits himself in women's clothing, disguising himself as an Amazon by the name of Zelmane, in an attempt to seduce the princess Philoclea. In dressing as a woman and performing the role of Zelmane, Pyrocles manipulates those around him and get past his love's over-protective father, the foolish King Basilius. He ultimately succeeds in this quest because of his intentions, which are entirely heteronormative in nature—-woo and marry a chaste maiden. However, this manipulation does not always work out to Pyrocles’ advantage: Zelmane encounters unwanted advances from both of Philoclea's parents, situations which require feats of strength not typically possessed by any woman, and obstruction from a family of idiotic servants who constantly get in the way of "her" quest for Philoclea's heart. But what is love without performance and trials?

Pyrocles' successful suit of Philoclea proves not only to Musidorus, but to the audience as well that it is Pyrocles’ masculinity which allows him to seduce his love interest. This quality does not diminish because the prince has outfitted himself in such a fashion that he appears to be female, but is instead emphasized. Disguised as a woman,

17. Sidney, The Countess of Pembroke's Arcadia, 136. 
he achieves what many other suitors, including Philoclea's cousin, failed to do: he bypasses Basilius’ protections and seduces his daughter. Philoclea’s relief once Zelmane reveals her true identity and her ability to accept her love for the "Amazon" can be seen as Sidney implying that this acceptance only occurs because of Pyrocles' status as an “acceptable” suitor, evidenced to Philoclea by her mother Gynecia’s obvious interest in the Amazon, whose true nature she has intuited, though her daughter remains unaware of this through much of the work due to the queen's jealous lust for the cross-dressed protagonist.

Chronologically, this story begins not with Pyrocles and his trials, but when Basilius, the King of Arcadia and father of Philoclea and her sister Pamela, relocates his family to a secluded forest because of a prediction from the Oracle at Delphos that Pamela would be stolen from him by a prince; Philoclea would "with Nature’s bliss embrace/An uncouth love, which Nature hateth most;” his daughters' two suitors would kill him; a foreign power would sit on his throne; and that he and Gynecia would become adulterers. ${ }^{18}$ As a result of this dire prediction, Basilius and his wife Gynecia move into one pastoral lodge with Philoclea, while Pamela lives next door with the foolish shepherd Dametas, his wife Miso, and his daughter Mopsa. The king leaves a proxy on his throne and refuses to let any potential suitor near his daughters.

Upon seeing a picture of Philoclea and hearing of her circumstances, Pyrocles is almost instantly smitten with her. He resolves to adopt the apparel of an Amazon warrior woman, taking the name of Zelmane after a deceased friend. Pyrocles/Zelmane comes

18. Sidney, The Countess of Pembroke's Arcadia, 395. 
across Dametas one day in the Arcadian forest, the resulting confrontation causing her to “[forget] all Zelmaneship" and pull her sword on the foolish shepherd. ${ }^{19}$ Dametas, frightened by the sword-wielding woman, runs off to fetch his master, and Basilius immediately falls in lust with Zelmane, taking her home with him to meet his family. Basilius has Zelmane stay with him, Gynecia, and Philoclea, justifying his actions by stating that "the best in this country [...] suspect so excellent beauty being so weakly guarded.”20 Living with Basilius and his family should provide Pyrocles/Zelmane with the access to Philoclea he craves, but instead provides Gynecia and her husband with the opportunity to "court” him/her and thwart his quest for the princess' hand.

Pyrocles acquires the names Zelmane and Daiphantus (the latter of which he uses when he is in Greece after being shipwrecked) from the daughter of Plexirtus, the illegitimate, evil son of the king of Paphlagonia. After revealing his true identity to Philoclea, Pyrocles recounts the tale to her: the original Zelmane, out of love for Pyrocles, disguised herself as a page in order to serve him after he and Musidorus escaped from the lecherous queen Andromana, who had taken offense at the two cousins not wishing to bed her. Zelmane overtook them when they had barely cleared the castle, telling them that her name was Daiphantus and that she "was a nobelman's son of Iberia [...], [who,] having seen what [Pyrocles] had done in that court, had stolen from her father to follow [him]."21 She had cut off her golden curls; donned a white outfit; and

19. Sidney, The Countess of Pembroke's Arcadia, 143.

20. Sidney, The Countess of Pembroke's Arcadia, 144.

21. Sidney, The Countess of Pembroke’s Arcadia, 359. 
acquired a headpiece, shield, and lance. "[Her] horse [was] fair and lusty, which she rid so as might show a fearful boldness, daring to do that which she knew that she knew not how to do: and the sweetness of her countenance did give such a grace to what she did that it did make handsome the unhandsomeness, and make the eye force the mind to believe there was a praise in that unskilfulness. ${ }^{, 22}$ Despite this overt show of "manliness," which was quite unlike the fair Zelmane, Pyrocles kept thinking that he recognized the young page. However, not expecting a "male version” of Zelmane, he was unable to see Daiphantus as the same person.

Daiphantus continued on with their party, happily serving Pyrocles until they witness a horrific event: Plexirtus tricking two famous brother knights into killing each other. Zelmane is so ashamed of her father and fearful of Pyrocles' reaction should he find out her true identity that her health begins to decline rapidly. Pyrocles, of course, does not understand why Daiphantus has such a strong reaction to their deaths, nor does he understand why the page falls extremely ill. Zelmane finally reveals her true identity to Pyrocles on her death bed: "your page Daiphantus is the unfortunate Zelmane, who for your sake caused my as unfortunate lover and cousin, Palladius, to leave his father's court, and consequently both him and my aunt, his mother, to lose their lives. For your sake myself have become of a princess, a page, and for your sake have put off the apparel of a woman, and (if you judge not more mercifully) the modesty." ${ }^{23}$ Zelmane’s revelation and the lengths to which she goes out of love of Pyrocles shock the prince.

22. Sidney, The Countess of Pembroke's Arcadia, 359.

23. Sidney, The Countess of Pembroke's Arcadia, 365. 
Despite this shock, Pyrocles is fair to the maiden and does not judge her for her father's wrongdoings.

Before she dies, Zelmane asks Pyrocles to do several things for her: to think of her in kindness and pity instead of scorn; that he pardon her father for his terrible deeds and rescue him from the danger he had gotten himself into; that Pyrocles will take the name Daiphantus when he goes into Greece, where he desired to remain unknown; that Musidorus will take the name Palladius so "that his name yet may live upon the earth in so excellent a person”; and that they bury her someplace only they can find her until they return home from their journeys, then relocate her corpse so that Pyrocles could sometimes visit her. ${ }^{24}$ Pyrocles takes these wishes to heart, taking not only the name of the page Daiphantus as his own when he and Musidorus enter Greece and need to mask their true identities, but also using the name of Zelmane once he is in Arcadia and finds himself dressing as a woman so that he can get closer to Philoclea. Zelmane's crossdressing, unlike Pyrocles', ends not in marriage, but in death, possibly because she is a woman. It was against the law for women to act on the stage during Sidney's lifetime, and Zelmane's cross-dressing can be read as an extension of that-Zelmane is too weak to possibly pass as a man for long enough to seduce Pyrocles.

According to Stephen Orgel, Pyrocles’ transformation into and performance as a woman "alludes to the classic Herculean model, and moralizes it in a way that emphasizes both the arbitrary element in gender construction and the deep ambiguities

24. Sidney, The Countess of Pembroke's Arcadia, 367. 
implicit in cross-dressing.”25 The first appearance of Pyrocles as Zelmane the Amazon, which occurs when he accidentally reunites with his cousin, illustrates this "allusion” well: Musidorus spots Zelmane ("a lady who, because she walked with her side toward him, he could not perfectly see her face, but so much he might see of her that was a surety for the rest that all was excellent”) in an arbor, singing about her woes. ${ }^{26} \mathrm{He}$ quickly recognizes the voice as that of Pyrocles, however. Upon encountering his cousin in the arbor, Musidorus at first adopts a derisive attitude towards Zelmane's manner of dress ("he perceived indeed that it was Pyrocles thus disguised: wherewith not receiving so much joy to have found him as grief so to have found him”), berating Pyrocles for becoming “womanish” in his pursuit of love: ${ }^{27}$

Remember (for I know you know it) that if we be men, the reasonable part of our soul is to have absolute commandment, against which, if any sensual weakness arise, we are to yield all our sound forces to the overthrowing of so unnatural a rebellion; wherein how can we want courage, since we are to deal against so weak an adversary that in itself is nothing but weakness? [...] And truly I think hereupon it first gat the name of love; for indeed the true love hath that excellent nature in it, that it doth transform the very essence of the lover into the thing loved, uniting and, as it were, incorporating it with a secret and inward working. And herein do those kinds of love imitate the excellent; for as the love of heaven makes one heavenly, the love of virtue, virtuous, so doth the love of the world make one become worldly; and this effeminate love of a woman doth so womanize a man that, if he yield to it, it will not only make him an Amazon, but a launder, a distaff-spinner or whatsoever vile occupation their idle heads can imagine and their weak hands perform. ${ }^{28}$

25. Stephen Orgel, Impersonations: The Performance of Gender in Shakespeare's England (New York, NY: Cambridge University Press, 1996), 78.

26. Sidney, The Countess of Pembroke's Arcadia, 130.

27. Sidney, The Countess of Pembroke's Arcadia, 132.

28. Sidney, The Countess of Pembroke's Arcadia, 132-34. 
Musidorus' misogynistic argument calls women, and by extension Pyrocles (given that he is performing as a woman), weak. Musidorus’ argument portraying love as “womanish" occurs frequently in the early modern era. As stated by Amy Greenstadt, "According to Musidorus, Pyrocles's 'effeminate love’ will not only make him imitate inferior womanly activities, but will lead to immoral behavior., ${ }^{29}$ As the lover imitated the beloved, Musidorus thinks Pyrocles will become unreasonable and develop an "idle head." Pyrocles counters his cousin's rhetoric by telling Musidorus of his love for Philoclea and how disguising himself presents the only means of bypassing Basilius’ protections over his daughter. "Pyrocles defends himself with some surprisingly forceful Platonic logic. He says that it is in the nature of love to imitate the beloved; that since women are virtuous imitating them cannot be vicious; and that no human being's virtue is complete unless it encompasses the virtue of women as well as men [...] [and that] women are won by imitation; what they want are versions of themselves. ${ }^{30}$ Pyrocles and Musidorus share the similar point that the lover becomes more like the beloved, but Pyrocles, who (at the time of this argument) has a love to emulate, has a more positive opinion of that which he loves (woman) than his cousin, who has yet to experience this emotion. Eve Kosofsky Sedgwick says something similar in her reading of the youth spoken of in Shakespeare's sonnets: "The youth has his womanlike features, but in the Gestalt of the Sonnets, he is a very touchstone of maleness: he represents the masculine

29. Amy Greenstadt, Rape and the Rise of the Author: Gendering Intention in Early Modern England (Burlington, VT: Ashgate Publishing Company, 2009), 40.

30. Orgel, Impersonations, 79, 87. 
as pure object. ${ }^{\text {31 }}$ Once Musidorus has acclimated to Pyrocles’ cross-dressed state, the younger man goes on at his cousin's request to explain how he ended up living with the king and his family, as well as informing him that both Basilius and his wife are in love with him (Gynecia has intuited Zelmane’s actual sex, though she does not know his actual identity).

As important a role as gender plays in The New Arcadia, the early modern world believed that there was only one true sex. Thomas Laquer expounds upon this "one sex model” in his book Making Sex: Body and Gender from the Greeks to Freud, stating that early modern scientists viewed women as "imperfect" men, their genitalia turned insideout to form the female womb. The "sameness" which men and women were thought to exhibit insofar as gender was concerned carries over into the language of the time:

The absence of a precise anatomical nomenclature for the female genitals, and for the reproductive system generally, is the linguistic equivalent of the propensity to see the female body as a version of the male. Both testify not to the blindness, inattention, or muddleheadedness of Renaissance anatomists, but to the absence of an imperative to create incommensurable categories of biological male and female through images or words. Language constrained the seeing of opposites and sustained the male body as the canonical human form. And, conversely, the fact that one saw only one sex made even words for female parts ultimately refer to male organs. There was in an important sense no female reproductive anatomy, and hence modern terms that refer to it—vagina, uterus, vulva, labia, fallopian tubes, clitoris—cannot quite find their Renaissance equivalents. ${ }^{32}$

The physical descriptions of Pyrocles, both as himself and in his disguised form, adhere to the above "sameness" by using similar language, especially in the portrayal of his/her hair. When Musidorus points his shipwrecked cousin out to two shepherds in the

31. Eve Kosofsky Sedgwick, Between Men: English Literature and Male Homosocial Desire (New York, NY: Columbia University Press, 1985), 44.

32. Thomas Laquer, Making Sex, 96. 
beginning of the work, Sidney depicts the young prince as having very long hair typical of young Greek men at the time. Before recognizing his cousin's voice in the Arcadian forest, Musidorus expounds upon the "beautiful Amazon" and her tresses at length:

Well might he perceive the hanging of her hair in fairest quantity in locks, some curled and some as it were forgotten, with such a careless care and an art so hiding art that she seemed she would lay them for a pattern whether nature simply or nature helped by cunning be the more excellent: the rest whereof was drawn into a coronet of gold richly set with pearl, and so joined all over with gold wires and covered with feathers of divers colors that it was not unlike to an helmet, such a glittering show it bare, and so bravely it was held up from the head. ${ }^{33}$

Hair features prominently in descriptions of Pyrocles' appearance, regardless of the gender he exhibits, and bears some similarity to that of boy actors during Sidney's lifetime. Mary Bly writes that boy actors on the early modern stage would keep their hair long, even when not in a role. This "feminine" trait of the young men of the theater was the source of both controversy over their gender play and lust from both men and women.

Age constitutes another similarity between Pyrocles and the boy actors of the early modern theater, as their youth provides them with certain qualities an older man would not possess, such as a higher voice and the inability to grow facial hair. According to the text, Pyrocles' age lies between sixteen and seventeen years old, while Musidorus is "elder by three or four years." ${ }^{34}$ The early modern English stage was known for boy actors playing women's roles, as their voices were higher and they were able to pass as feminine with some degree of ease when properly attired.

[Whitefriar's] Articles of Agreement refer to the actors as 'the said younge men or ladds', and those 'ladds' were probably between 14 and 17 years of age.

33. Sidney, The Countess of Pembroke's Arcadia, 130.

34. Sidney, The Countess of Pembroke's Arcadia, 259-60. 
Reavley Gair estimates that the Children of Paul's were 19-20 in 1606, and Ann Blake argues that in 1604-6 the Blackfriars troupe included 17-year-olds. On the other hand, Shen Lin has suggested that younger boys were constantly recruited to complement older 'youths'. The only information we have regarding a known Whitefriars actor is about William Barksted, who was under 21 in January 1609, but of age by September of 1610, making him approximately 17 when the Whitefriars opened. Barksted's age and the term 'ladds' in the Articles of Agreement suggests that Whitefriars boys may well have been old enough to marry; in 1602, the Dowager Countess of Leicester apparently married 'one of the playing boyes of the chappell'. ${ }^{35}$

One can therefore deduce that Pyrocles' own performance adhered to the same techniques and mannerisms that these young actors would have applied to their art, making a man passing as a woman especially believable during the time in which Sidney wrote The New Arcadia. Pyrocles' attire reveals not only the prince's commitment to wooing and marrying Philoclea, but also his youth, given that he can even carry out such a performance. Musidorus, being somewhere between nineteen and twenty-one, would not likely have been able to pass as a woman by any stretch of the imagination, which therefore meant that he had to seek an alternate form of disguise in order to perform his suit of Pamela.

As argued by Victor Stretcowicz, Pyrocles’ cross-dressing, because of its motive, "falls within the moral constraints of long established chivalric codes," thereby further justifying his "womanish apparel” and solidifying the argument he gives his cousin. ${ }^{36}$ Musidorus eventually accepts this explanation "as full of care to help his friend as before

35. Mary Bly, Queer Virgins and Virgin Queans on the Early Modern Stage (New York, NY: Oxford University Press, 2000), 127.

36. Victor Stretcowicz, “Categorizing Redirection in Sidney’s New Arcadia, Narrative Strategies in Early English Fiction, eds. Wolfgang Gortschacher and Holger Klein (Lewiston, NY and Salzburg, Germany: The Edwin Mellen Press, 1995), 139. 
he was to dissuade him,” and Pyrocles convinces him to hide in the woods so he might catch a glimpse of the fair Philoclea and therefore better understand his love for the fair maiden. ${ }^{37}$ When he does this, however, Musidorus falls in love with Pamela and follows his cousin's example, disguising himself not as a woman but as a shepherd named Dorus. Dorus' performance is, in some ways, more complicated than Zelmane's: where Pyrocles must perform a gender other than his own and must navigate how to win Philoclea's heart while dealing with jealous and foolish lovers who also happen to be the princess’ parents, Zelmane’s status as a princess justifies her being treated as an equal to Basilius and his family. Musidorus, however, must perform the role of someone of a much lower class than his love, which not only means that he must reside in the house with Dametas, Miso, and Mopsa (though it eventually works to his advantage), but that he cannot convince Pamela of the validity of his suit by speaking to her directly. Instead, he must flirt with the hideous Mopsa in Pamela's presence, conveying his interest in her through a third party. Dorus also tells Mopsa/Pamela the story of the trials of Prince Musidorus, capitalizing on the former's almost absurd lack of intellect to come clean about his true identity without having to get Pamela alone, a feat which would have been even more difficult than Pyrocles’ challenge of evading Gynecia’s jealous eyes and Basilius' bumbling suits. Musidorus also does not have the defense of being of the "fairer sex," thereby rendering his being alone with Pamela, even if he had been performing as someone of his actual social standing, extremely improper. Pyrocles, for

37. Sidney, The Countess of Pembroke's Arcadia, 151. 
all his woes and complaints, acknowledges the challenges his cousin faces, wondering how Musidorus, as a prince, could abide such treatment.

Zelmane's too-gracious host Basilius firmly believes his guest's ruse and falls madly in love with her, following her around with "serviceable steps" (despite his social status), even in front of his wife, who would find the entire situation hilarious were she not mad with jealous lust, herself. ${ }^{38}$ Basilius' affections are laughable not only to Pyrocles/Zelmane, who clearly has no interest in the king and constantly sidesteps his advances, but also to the audience, who knows that his suit has to be unsuccessful in the end because it contravenes socially accepted gender norms. Pyrocles' suit of Philoclea, on the other hand, despite the cross-dressed state of the former, does adhere to said gender norms, rendering it more "acceptable” than Basilius' affections. The foolish king continually seeks Zelmane out, awkwardly propositioning her when he would catch her alone.

[He] presented himself unto her, falling down upon both his knees and holding up his hands, as the old governess of Danae is painted when she suddenly saw the golden shower, "O heavenly woman, or earthly goddess," said he, "let not my presence be odious unto you, nor my humble suit seem of small weight in your ears. Vouchsafe your eyes to descend upon this miserable old man, whose life hath hitherto been maintained but to serve as an increase of your beautiful triumphs. You only have overthrown me, and in my bondage consists my glory. Suffer not your own work to be despised of you, but look upon him with pity, whose life serves for your praise."39

Zelmane's encounter with Basilius horrifies the Amazon, who clearly cannot entertain the king's suit, given his age and marital status. The audience can see that Pyrocles-as-

38. Sidney, The Countess of Pembroke's Arcadia, 321.

39. Sidney, The Countess of Pembroke's Arcadia, 323-24. 
Zelmane views this suit as unfeasible, given his true sex, which lends further credence to Zelmane’s open disgust at Basilius' words. However, she quickly finds a way to use the king’s bumbling declaration and subsequent mortification to her advantage:

Zelmane, lifting up her face as if she had received a mortal injury of him, "And is this the devotion your ceremonies have been bent unto?" [...] 'Enjoying,' quoth you! Now little joy come to them that yield to such enjoying.”

[...]At length, with a wan mouth, he was about to give a stammering answer, when it came into Zelmane's head by this device to make her profit of his folly; and therefore with a relented countenance thus said unto him, "Your words, mighty Prince, were unfit either for me to hear or your to speak, but yet the large testimony I see of your affection makes me willing to suppress a great number of errors. Only thus much I think good to say, that the same words in my lady Philoclea's mouth, as from one woman to another, so as there were no other body by, might have had a better grace, and perchance have found a gentler receipt." 40

Zelmane uses Basilius' love for her, his shame at her chastisement for his inappropriate behavior, and his belief that she is truly a woman to her advantage in order to convince Basilius to leave his daughter alone with her, finally succeeding in thwarting Gynecia’s jealous, seemingly ever-present gaze.

Further evidence of Basilius’ blindness regarding his cross-dressed love object appears when Phalantus of Corinth arrives in the Arcadian forest and asks to hold a threeday tournament in honor of his mistress, Artesia, "to give her beauty the principality over all other." ${ }^{41}$ Basilius only allows this tournament to take place because he wants to impress Zelmane with his abilities as a host. At the beginning of the tournament, Phalantus, well-known for his chivalric feats, challenges all the knights of Arcadia to a jousting match of six rounds, judged by Basilius, in which the competing knight would

40. Sidney, The Countess of Pembroke's Arcadia, 324.

41. Sidney, The Countess of Pembroke's Arcadia, 156. 
place a picture of the woman whose beauty he was defending next to Phalantus’ portrait of Artesia. The winner of the contest would win both portraits as well as honor for himself and the woman whose beauty he was defending. Several knights from various kingdoms tried and failed, losing portraits of many beautiful women, including the woman from whom Pyrocles acquired the name Zelmane.

The honorable knights of Arcadia fall one by one, including one jousting in honor of the queen Gynecia, until one man comes forward bearing a portrait of Philoclea. This drives Zelmane mad with jealousy, even though the knight loses. She finds an old, rusty suit of armor and strikes the shield to signal her challenge, getting there just before another knight, dressed entirely in black. The identities of both knights remain unknown and the two get into a fight, eventually broken up by Basilius. The king determines that the knight in the shoddy armor would compete against Phalantus, and the unknown man defeats the champion soundly.

There is no doubt in the minds of the characters that the knight in shoddy armor is a man, especially having spoken to him at length, until Basilius decides to introduce him to Zelmane, at which point the knight removes his helmet and reveals that he is none other than the "lady" herself. Despite this episode, no one questions Zelmane's gender, least of all Philoclea and Basilius. The knight in black reveals himself later as Pyrocles’ cousin, Musidorus, who intended on fighting in Pamela's honor.

Philoclea, like her father, has no doubts regarding Zelmane’s gender for several months, especially as Zelmane cannot get her alone for even a minute to reveal the truth to her. Unlike her father, however, Philoclea’s love for Zelmane develops over time, rather than manifesting as instantaneous, ignorant lust. As the two get closer, Philoclea 
begins adopting Zelmane's mannerisms, doing all she can to spend more time with the

Amazon. Eventually, she begins desiring for them to be together forever, trying to come up with a societally acceptable way for them to remain together:

For whether it were that her wit in continuance did find that Zelmane's friendship was full of impatient desire having more than ordinary limits, and therefore she was content to second Zelmane though she herself knew not the limits, or that in truth true love, well considered, have an infective power, at last she fell in acquaintance with love's harbinger, wishing. First she would wish that they two might live all their lives together, like two of Diana's nymphs. [...] Then would she wish that she were her sister, that such a natural band might make her more special to her. [...] Then grown bolder, she would wish that either herself or Zelmane a man, that there might succeed a blessed marriage betwixt them. But when that wish had once displayed his ensign in her mind, then followed whole squadrons of longings so that it might be, with a main battle of mislikings and repinings against their creation, that so it was not. ${ }^{42}$

As Philoclea understands her own circumstances, she and Zelmane cannot love oneanother. Given that she thinks she loves another woman, she compares herself to ambitious men, though she suffers a worse fate, as she accepts her love for Zelmane (“Away then all vain examinations of why and how. Thou lovest me, excellent Zelmane, and I love thee”) rather than accepting said love's impossibility (as far as she knows). ${ }^{43}$

However, seeing her mother's affections for the Amazon, Philoclea justifies her own "unnatural" desires with the evidence that two women she considers wiser and more virtuous than she love other women, thereby reasoning that it either must not be that “impossible" for her to love another woman or that it somehow adheres to acceptable societal standards. This logic enables her to embrace her love for Zelmane, regardless of the other's gender:

42. Sidney, The Countess of Pembroke's Arcadia, 239-40.

43. Sidney, The Countess of Pembroke's Arcadia, 244. 
[...]doth not she vouchsafe to love me with like ardour? I see it; her eyes depose it to be true. What then? And if she can love poor me, shall I think scorn to love such a woman as Zelmane? Away then all vain exclamations of why and how. Thou lovest me, excellent Zelmane, and I love thee.' And with that, embracing the very ground whereon she lay, she said to herself (for even to herself she was ashamed to speak it out in words) 'O my Zelmane, govern and direct me, for I am wholly given over unto thee. ${ }^{44}$

While using Zelmane and Gynecia to justify her own love, Philoclea purposefully ignores her father's feelings for that same "lady," as his feelings are apparently of the “acceptable” variety. The lust Gynecia and Basilius both have for Pyrocles/Zelmane shows yet another parallel between the young cross-dresser's story and the boy actors of the early modern English stage. Mary Bly states in Queer Virgins and Virgin Queans on the Early Modern Stage that "the body of the cross-dressed actor is aggressively eroticized." ${ }^{45}$ Men and women alike pursued boy actors, and the character of Pyrocles embodies this lust and pursuance in the absurdity of the suits he must endure whilst in his cross-dressed state.

Philoclea's "unnatural” isolation in the Arcadian forest ultimately (albeit indirectly) results in her "unnatural” desire for the Amazon Zelmane, since, had Basilius not panicked at the words of the Oracle, Pyrocles would likely have either never heard of the princess or would have been able to pursue her in a more conventional manner. According to an article by Sallie Anglin on the environment of Arcadia,

Near the beginning of Book One, Pyrocles describes Arcadia, a pastoral fantasy, as the perfect place for love [...] The optimism of Pyrocles' vision is created in part by his rapturous conception of love; however, what he emphasizes is the union between the animals, the plants, the people, and even the non-living

44. Sidney, The Countess of Pembroke's Arcadia, 244.

45. Bly, Queer Virgins and Virgin Queans on the Early Modern Stage, 23. 
elements of the environment. In the forest, life is defined through the interconnectivity between the material objects of the environment. The inhabitants of Arcadia find that solitude and confinement, conversely, prevent growth and transformation. Physical separation renders the characters inert and uncooperative in Arcadia's communal ecology. [...] [The] material relationships in the New Arcadia between the elements of the natural world result in an environmentally embedded subject that is alternately de-centered, re-centered, and transformed in relation to its environment, and that the environment itself is altered by human thought and action. ${ }^{46}$

She goes on to argue that, while the forest does give the feeling of solitude and confinement, the characters never actually experience true solitude: someone, whether the trees or another human, is always either watching or within earshot of the seemingly isolated individual. This proves especially problematic for Zelmane, who cannot seem to get a spare moment to herself. Every time she walks through the forest singing of her plight of being unable to reveal herself to Philoclea or how much she loves the princess, someone ends up approaching her afterwards, having heard every word of her song. This results in both Musidorus recognizing her as his cousin Pyrocles and Basilius' laughably awkward suit.

Zelmane, when she finally reveals herself to Philoclea (after shaming Basilius into fetching his daughter for her), fears the princess' reaction to the news that she is not, in fact, a woman. He vows never to lie to her again and beseeches her to listen to him: "But alas, whither goest thou, my tongue, or how doth my heart consent to adventure the revealing his nearest touching secret? But peace, fear, thou comest too late when already the harm is taken. Therefore I say again, $\mathrm{O}$ only princess, attend here a miserable miracle

46. Sallie Anglin, "Material Romance: Embodiment, Environment, and Ecology in Sidney’s New Arcadia," Sidney Journal, 30.2 (2012), 87. 
of affection." ${ }^{47}$ Rather than being upset, however, "[the] joy which wrought into Pygmalion's mind, while he found his beloved image was softer and warmer in his folded arms [...] creepingly entered into Philoclea, till her pleasure was fully made up with the manifesting of his being, which was such as in hope did overcome hope., ${ }^{48}$ Philoclea rejoices at the revelation that her heretofore "unnatural" desires are not actually “forbidden,” bringing her great joy and relief, though she now must help maintain her love's secret.

However, Pyrocles can only be victorious in his quest to reveal himself to his love and earn her acceptance for a short while: Philoclea quickly becomes confused as to how she should address Pyrocles, ultimately choosing to continue referring to her love as Zelmane, "for so I love to call thee, since in that name my love first began, and in the shade of that name my love shall best lie hidden. ${ }^{49}$ Despite Philoclea's joy at her love’s revelation, she remains a woman of virtue and wishes to stay chaste, asking that Pyrocles keep her "then still worthy to be beloved." ${ }^{50}$ Pyrocles delights his love with the story of how he and Musidorus arrived in Arcadia, but soon enough decides he would rather kiss Philoclea's lips than continue the tale. When Philoclea finally convinces Pyrocles to go back to telling her about his adventures, Dametas’ wife Miso interrupts them, chastising

47. Sidney, The Countess of Pembroke’s Arcadia, 328.

48. Sidney, The Countess of Pembroke’s Arcadia, 329.

49. Sidney, The Countess of Pembroke's Arcadia, 330.

50. Sidney, The Countess of Pembroke's Arcadia, 240, 330. 
Philoclea for "[keeping] company with strangers” rather than staying inside. ${ }^{51}$ Philoclea counters that her father sent her to speak with Zelmane, and Miso storms off to report to Gynecia.

Gynecia, unlike Basilius and Philoclea, intuits Zelmane’s actual sex. Like her husband, she falls madly in lust with the cross-dressed "Amazon,” to the point where she covets him jealously, doing her best to make sure that the two are never alone together. Pyrocles laments his inability to be alone with his love to his cousin: "And so jealous is she of my love to her daughter that I could never yet begin to open my mouth to the unevitable Philoclea but that her unwished presence gave my tale a conclusion before it had a beginning."52 Philoclea, therefore, is always surrounded by people: either her sister Pamela, Dametas’ wife and daughter, or her parents. Zelmane tries several times to get Philoclea alone so that she might reveal herself, but to no avail: “Alas, incomparable Philoclea, thou ever seest me, but dost never see me as I am. Thou hearest willingly all that I dare say, and I dare not say that which were most fit for thee to hear. Alas, who ever but I was imprisoned in liberty, and banished being still present? To whom but me have lovers been jailors, and honour a captivity?”53 Gynecia’s suit of Pyrocles/Zelmane is, like her husband's, laughable and "impossible," as a married woman should not harbor such unchaste thoughts of someone to whom she is not wedded.

51. Sidney, The Countess of Pembroke's Arcadia, 376.

52. Sidney, The Countess of Pembroke's Arcadia, 150.

53. Sidney, The Countess of Pembroke’s Arcadia, 321. 
Gynecia and Zelmane both use the attitudes toward relationships between two females which were prevalent during that time to their personal advantage over the course of the story. Gynecia would sit at Zelmane's bedside and kiss her, while Zelmane would use her womanly outward appearance to spend as much time at Philoclea's side as possible. However, in Zelmane’s case, her ruse would occasionally backfire on her: the sisters invite her to bathe with them one day and she must decline, claiming that she has a cold. "Zelmane would have put to her helping hand, but she was taken with such a quivering that she thought it more wisdom to lean herself to a tree and look on." ${ }^{\text {,5 }}$ She cannot even help the girls prepare for their bath given her nearly uncontrollable lust for Philoclea, the early modern audience realizing that Pyrocles/Zelmane aiding in this activity would be unchaste on the parts of all involved, albeit unintentionally on those of Basilius’ daughters.

Basilius and Gynecia smother Zelmane with unwanted attention, the former throwing himself at her feet in various absurd fashions and the latter constantly watching Zelmane, thwarting her efforts to woo Philoclea by making sure they are never alone together.

[B]etween her and him, the poor Zelmane received a tedious entertainment, oppressed with being loved almost as much as with loving. [...] Once Zelmane could not stir but that (as if they had been poppets, whose motion stood only upon her pleasure) Basilius with serviceable steps, Gynecia with greedy eyes, would follow her. [...] Zelmane betwixt both, like the poor child whose father, while he beats him, will make him believe it is for love; or like the sick man, to whom the physician swears the ill-tasting wallowish medicine he proffers is of a good taste. Their love was hateful, their courtesy troublesome, her presence cause of her absence thence where not only her light but her life consisted. ${ }^{55}$

54. Sidney, The Countess of Pembroke's Arcadia, 285.

55. Sidney, The Countess of Pembroke’s Arcadia, 321. 
When Miso informs the queen that Zelmane and Philoclea are outside alone together, Gynecia has to make a conscious effort to quell her jealousy to keep from revealing Zelmane’s secret, thereby causing the expulsion of Pyrocles/Zelmane from Arcadia (or resulting in his death). Basilius, however, reacts with confusion, simply telling his wife that there exist worse people for their daughter to befriend.

Even though Pyrocles had to endure his cousin’s scoffing; had a mother- and father-in-law who would rather he be in their respective beds than that of their daughter; and had to perform multiple feats that one would typically find unsuitable for a lady, even one of Amazon genealogy, the prince Pyrocles is ultimately able to achieve the goal of seducing his love. Despite his cousin Musidorus’ derision and misgivings, Pyrocles continues his ruse as the Amazon Zelmane, gradually winning the heart of Philoclea, who was prepared to give up her chastity for the sake of the great Amazon Zelmane’s love. By succeeding in this endeavor, he fulfils his own prophesy, proving himself a man both in spite of and because of his attire. Pyrocles' maleness and Philoclea's status as an unmarried, chaste maiden enable the prince's suit is able to succeed where Basilius and Gynecia’s suits of Zelmane were laughable failures. 


\section{THE PRINCE(SS) AND THE PLAYS (WITHIN THE PLAY)}

The Prince in Margaret Cavendish’s The Convent of Pleasure, similar to Sidney’s Pyrocles, finds himself cross-dressing to seduce his chosen partner. Lady Happy, with whom the Prince falls in love, locked herself away in a Convent after her father's death, only allowing other unmarried maidens and widows inside. The Prince/Princess must endure not the lust of his beloved's parents, but Lady Happy's derisive opinions on marriage, childbirth, and child rearing, presented in the form of plays within the play. Like Pyrocles, the Prince's suit succeeds, showing once more that, despite a possibly unorthodox beginning, the relationship between the two lovers still adheres to societal norms and can therefore still be "allowed" to succeed.

The Convent of Pleasure constitutes one of many plays which Cavendish wrote with no intention of having performed, as she thought her works would bore people. The play opens with three gentlemen acting as a sort of chorus, introducing the character of Lady Happy, the only child of the recently deceased Lord Fortunate, describing this Lady as being "extream handsome, young, rich, and virtuous," and the men talking about her joke that these features are "too much for one Woman to possess [alone]." ${ }^{56}$ They decide that obvious solution to this would be for one of them "to have her [as his wife]." 57

Enter the Lady herself with her servants. Lady Happy expresses her belief that gifts should be bestowed on those who are lacking them, "so that if I should place my

56. Cavendish, The Convent of Pleasure, Act I Scene 1.

57. Cavendish, The Convent of Pleasure, Act I Scene 1. 
gifts rightly, I must Marry one that's poor, old, ill-favoured, and debauch’d.”58 The Lady shows further derision towards marriage when confronted by her advisor, Madam Mediator, to whom she presents the argument that, if she married "the best of Men, if any best there be," she would be subject to "more crosses and sorrows than pleasure, freedom, or happiness.” 59 She continues justifying her decision to establish the Convent and lock herself away from the company of men by enumerating the things she might do as an unmarried woman (such as becoming a “Courtizan”) and explaining why none of them would benefit her. Lady Happy concludes this forceful, anti-male rhetoric by stating that "since there is so much folly, vanity and falsehood in Men, why should Women trouble and vex themselves for their sake; for retiredness bars the life from nothing else but Men.”60 The argument here shows the disdain for marriage found in many of Cavendish's works, providing the audience with what appears to be a sound, logical argument about the woes men bestow upon their female counterparts and why women should therefore "incloister" themselves away from them.

Madam Mediator counters this argument, advocating that Lady Happy maintain a typical, heteronormative, view on men, informing her that women who "incloister themselves, bar themselves from all other worldly pleasures.” 61 Lady Happy has a response to this as well, stating that those who lock themselves away for religious

58. Cavendish, The Convent of Pleasure, Act I Scene 2.

59. Cavendish, The Convent of Pleasure, Act I Scene 2.

60. Cavendish, The Convent of Pleasure, Act I Scene 2.

61. Cavendish, The Convent of Pleasure, Act I Scene 2. 
purposes are not doing what the gods would want them to do, as depriving oneself of pleasure wearies one more than it brings joy or pleasure. Madam Mediator asks how Lady Happy thinks she is not shutting herself off from pleasure when the greatest pleasure is supposedly the conversation of men, to which the Lady replies that "Men are the only troublers of Women; for they only cross and oppose their sweet delights, and peaceable life.” ${ }^{62}$ Lady Happy's arguments against men, referring to them as a source of more anguish than happiness for the female party, are likely a reflection on the marriage of Cavendish’s parents: Margaret’s father died long before her mother, who mourned her husband for the rest of her life.

After this conference with Lady Happy, Madame Mediator encounters a group of men distraught by this news of the Convent and informs them that they have no hope of coaxing Lady Happy out of her isolation. The men ask if Madam Mediator can be the prioress of the Convent and allow them access, but to no avail:

Lady Happy is Lady-Prioress her self, and will admit none of the Masculine Sex, not so much as to a Grate, for she will suffer no Grates about the Cloister [...] Also, her House, where she hath made her Convent, is so big and convenient, and so strong, as it needs no addition or repair [...], [she] hath Women for every Office and Employment: for though she hath not above twenty Ladies with her, yet she hath a numerous Company of Female Servants, so as there is no occasion for Men. ${ }^{63}$

The men do not seem to understand what the widow has told them, Lady Happy’s lack of need or want for male companionship baffling them, and ask for clarifications. They accuse the Lady of having "Heretical Opinions” which “ought not to be suffer'd” and

62. Cavendish, The Convent of Pleasure, Act I Scene 2.

63. Cavendish, The Convent of Pleasure, Act II Scene 1. 
propose that she be forced to marry a severe husband as punishment. ${ }^{64}$ Madam Mediator tells them to take their complaints to the State in the form of a petition for redress. The men thank her for her wisdom and depart.

After a short scene in which Lady Happy explains the Convent’s seasonal decorations to the other Ladies, Madam Mediator encounters Lady Amorous and Lady Vertue discussing their respective marriages outside the Convent's walls, providing the audience with the first conflicting opinion of marriage within the play: while being wed does not suit Lady Amorous, Lady Vertue cannot be happier. Madam Mediator interrupts their conversation with news of a new arrival to the Convent: "a great Foreign Princess [...][,] a Princely brave Woman truly, of a Masculine Presence." ${ }^{\prime 65}$ The news fascinates the two Ladies, and they implore Madam Mediator to explain how the Convent works. Lady Vertue wishes that she could see inside, but her status as a married woman renders this impossible.

Act II, Scene 4 shifts back to the men, who are attempting to devise a way to get the Ladies out of the Convent. Ultimately, Monsieur Take-Pleasure proposes that they disguise themselves as women in order to infiltrate the Convent, but Monsieur Adviser disagrees with that idea, as they will "discover” (reveal) themselves:

We cannot avoid it, for, our very Garb and Behaviour; besides, our Voices will discover us: for we are as untoward to make Courtsies in Petticoats, as Women are to make Legs in Breeches; and it will be as great a difficulty to raise our Voices to a Treble-sound, as for Women to press down their Voices to a Base;

64. Cavendish, The Convent of Pleasure, Act II Scene 1.

65. Cavendish, The Convent of Pleasure, Act II Scene 3. 
besides, we shall never frame our Eyes and Mouths to such coy, dissembling looks, and pritty simpering Mopes and Smiles, as they do. ${ }^{66}$

Monsieur Courtly concurs with Monsieur Take-Pleasure, arguing that they could enter the Convent as "strong lusty Country Wenches, that desire to serve them in Inferior Places, and Offices, as Cook-maids, Laundry-maids, Dairy-maids, and the like,” but Monsieur Facil retorts that he would not make a very good cook-, laundry-, or dairymaid. ${ }^{67}$ Monsieur Take-Pleasure replies that they could also brew beer or work in the gardens or with the swine, which devolves into a conversation about drinking. The men eventually give up on the idea of cross-dressing as a means of gaining access to the Convent.

Act III, Scene 1 provides the audience their first sighting of the Prince(ss). Here, s/he and Lady Happy praise each other's perfections, and the Princess begs for Lady Happy to allow her to act as her "masculine servant.” The Lady readily agrees to this idea and another of the Ladies of the Convent enters to ask if the two are ready to see the plays about marriage, prepared as entertainment and performed as plays within the play over the rest of the act.

Act IV opens with Lady Happy bemoaning her love for the Princess, as they both are women and Nature cannot alter itself to suit such "unnatural” affections. The Princess enters, dressed as a male shepherd, after this short lament and asks whether she offends Lady Happy with her presence. The Lady confesses to loving her servant more than she ought, and the Princess quells her fears. The two embrace and kiss before

66. Cavendish, The Convent of Pleasure, Act II Scene 4.

67. Cavendish, The Convent of Pleasure, Act II Scene 4. 
entering a pastoral scene that is part of a new play. The play, like the subsequent one, is not a portrayal of the negative aspects of marriage, unlike the plays in Act III, but a love story which ends in the marriage of Lady Happy and the Prince(ss)'s characters. The apparent shift in attitude regarding marriage accompanies a shift in author: the line "Nothing, Sweetest Mistress, that pleases you, can displease me" is the last line of the play which can be attributed to the Duchess with any certainty. ${ }^{68}$ William Cavendish, her husband, wrote at least part of the end, if not the entire thing.

After the pastoral play "vanishes,” the Princess stands alone onstage arguing with Mars, the Roman god of war:

What have I on a Petticoat, Oh Mars! thou God of War, pardon my sloth; but yet remember thou art a Lover, and so am I; but you will say, my Kingdom wants me, not only to rule, and govern it, but to defend it: But what is a Kingdom in comparison to a Beautiful Mistress? Base thoughts flie off, for I will not go; did not only a Kingdom, but the World want me. ${ }^{69}$

The Prince's argument bears some similarity to that which Pyrocles presents to Musidorus upon encountering him in the Arcadian forest, justifying the Prince's crossdressing as an act of love and not of true transgression, his ultimate aims falling within societal norms. The Prince's actions may be even less subversive than Pyrocles, as they aim to end Lady Happy’s “unnatural” self-isolation. The Princess exits and Lady Happy enters, begging the gods to strike her dead rather than letting her fall in love with an unsuitable partner and therefore fall into disgrace. Madam Mediator and the Princess reenter the scene and argue about Lady Happy's appearance: the Lady's advisor thinks she

68. Cavendish, The Convent of Pleasure, Act IV Scene 1.

69. Cavendish, The Convent of Pleasure, Act IV Scene 1. 
has grown pale and thin, but the Princess finds her resplendent. The three exeunt and the scene reopens with another play, in which the Princess plays Neptune and Lady Happy plays a Sea-Goddess.

Act V opens with the Princess once more in male apparel, dancing with Lady Happy and the other members of the Convent when Madam Mediator enters in a frenzy, announcing that a man disguised as a woman has infiltrated the Convent. The Princess tells Madam Mediator that she can search her, but will find nothing, to which Madam Mediator replies that the Princess seems the most likely suspect. The Princess retorts that "the Man is disguised like a Woman, and I am accoustred like a Man.,70 This argument shatters, however, when an ambassador from the Prince's kingdom arrives. Now “unmasked,” the Prince informs his ambassador that Lady Happy has imprisoned him, not the government. Madam Mediator panics, hoping that the Prince will not bring an army to take all the women from the Convent, and the Prince replies that they will leave the other women alone.

Madam Mediator, in tears, informs Lady Happy's other suitors of the Princess' true identity. She asks that the men keep the gossip to themselves, but the government already started preparing to receive the Prince and consider the match advantageous (for them). It was common for members of the upper classes to require permission from their monarchs to marry, and many marriages occurred not defined by love but potential political benefits, a policy which caused much bitterness between various courtiers and monarchs.

70. Cavendish, The Convent of Pleasure, Act V Scene 1. 
Act V Scene 3 takes place after the wedding of Lady Happy (now referred to as "Madam" or "Princess") and the Prince. The newlyweds stay to eat and dance in order to please Madam Mediator, after which Lady Happy approaches Lady Vertue, inquiring as to whether she still has her Mimick (or fool), which she does. Lady Happy asks him if he would leave his Lady and go with her, which spawns an argument between Lady Happy and the Mimick. After bargaining with the Prince and engaging in a lengthy internal debate, the Mimick speaks the Epilogue.

Sir Philip Sidney’s New Arcadia and Margaret Cavendish’s The Convent of Pleasure both tell the story of a woman isolated from the rest of the world pursued by a man willing to go so far as to cross-dress in order to gain access to her and win her love. The former tells this tale from the perspective of the male pursuer, while, in contrast, the latter provides the point of view of his female quarry. The shift in focus, as well as The Convent of Pleasure being about eighty years older, can account for some of the minor differences between the two texts. However, the number of parallels contained therein make the two works appear to be more than just a similar plot line shared between pieces composed in different times, or even just Margaret Cavendish drawing from a plot she had read elsewhere in one of her own plays.

When William Shakespeare's King Lear uses a short side story from The New Arcadia in its Gloucester subplot, for instance, it merely expands upon the original idea of a son disguising himself to save his father from committing suicide by tricking him. Cavendish's use of the plot involving Pyrocles' suit of Philoclea, however, especially with the changes made to said plot and her opinion that romances provided women with unrealistic views and expectations of marriage, not only adapts The New Arcadia to a 
different time period, but also responds to and parodies what Cavendish would likely have thought Sidney was doing wrong in having produced it, though he never intended for his works to survive his death. The variations between the two texts as well as in the plays within the play staged by Lady Happy and the members of her Convent in Acts III and IV provide evidence of Cavendish’s derision toward romances.

Like Pyrocles, the Prince proves his masculinity by successfully seducing Lady Happy. However, Cavendish's telling of his journey shows the author's lack of respect for the romance genre, best exemplified by the character of Lady Happy. At the beginning of the play, the maiden rails against marriage, especially the suitors who seem to only want her for her wealth and social status, locking herself in a Convent, away from any men who might try to gain her favor. In Act III, as she finds herself falling in love with the Princess, she has her fellow Convent-dwellers stage plays about the woes associated with marriage, childbirth, and child rearing. Finally, in Act V, when she can no longer avoid marriage, she falls almost completely silent, the now revealed Prince informing his ambassador that will marry, while Lady Happy seems to have no say in the matter. Cavendish, later in life, was of the opinion that romances provided women with unrealistic views of marriage. The satire she provides in the form of Lady Happy, viewed as a commodity rather than a person, even by the man she loves, vividly illustrates this disdain.

Sir Philip Sidney died in the midst of writing The New Arcadia from complications arising from a gunshot wound to the thigh. Though Margaret Cavendish has not died by the time The Convent of Pleasure is finished, she, too, stops writing toward the end of the play. After Act IV Scene 1, there is a note which reads "Written by 
my Lord Duke.” This note repeats three times, but as no terminating note exists, many presume that William Cavendish, first Duke of Newcastle, wrote the entirety of the ending. While this does not conclusively prove that The Convent of Pleasure actually parodies The New Arcadia, it does provide a fascinating parallel between the two works.

The New Arcadia and The Convent of Pleasure both feature a character who either suspects or intuits the cross-dressed character's true sex. Additionally, these two characters function as the maternal figure to the cross-dresser's intended love, though they seem to act more in their own interests than those of the ones supposedly under their guidance, Gynecia jealously pursuing Zelmane and Madam Mediator abetting the men on the outside of the Convent who wish to marry Lady Happy for her money, keeping them informed of Lady Happy’s (and, by extension, the Princess’) actions. Gynecia seems to intuit Zelmane’s “maleness” from the beginning. However, she holds herself back from revealing this knowledge to her husband because she jealously covets him, as revealed by Pyrocles/Zelmane to his cousin Musidorus upon their first encounter in the Arcadian forest.

Madam Mediator, on the other hand, does not suspect that Princess of crossdressing until she catches her kissing Lady Happy: "No truly, only once I saw him kiss the Lady Happy; and you know Womens Kisses are unnatural, and me-thought they kissed with more alacrity then Women use, a kind of Titillation, and more Vigorous.”71 She does not say anything about this episode until much later, until the Prince divulges his true identity, so that she would not be seen as a jealous old maid. Gynecia and

71. Cavendish, The Convent of Pleasure, Act V Scene 2. 
Madam Mediator both confront their respective cross-dressers, and both are interrupted after the disguised male denies their allegations, Gynecia by Basilius and Madam Mediator by one of the Prince's ambassadors, who reveals the Prince's identity.

Madam Mediator's character can be said to be making fun of Gynecia's suit of Pyrocles/Zelmane when she tells Monsieur Take-Pleasure and his cohort that she did not want to express her suspicions of the Princess' true sex because she did not wish to appear jealous of the Princess’ affections for Lady Happy. Gynecia very obviously envies Zelmane’s love for Philoclea, doing everything in her power to keep the two apart, despite the absurdity of her love for the cross-dressed “Amazon.” Pyrocles/Zelmane ultimately thwarts her efforts, using her husband's equally absurd and illogical feelings to get Philoclea alone and reveal his true identity to her.

Where Pyrocles struggles to get Philoclea alone and away from her mother's jealous gaze, the Prince seems to have no such issues. Despite this, he does not reveal his true gender to his love interest of his own volition. One might read this reluctance to reveal himself as Cavendish implying that Pyrocles should not realistically have exposed himself to Philoclea, as the consequences of her father learning of this deception would likely have been dire. On the other hand, one of the Prince's ambassadors reveals his identity while threatening the invasion of the kingdom in which Lady Happy resides unless the Prince returns home. As no one (other than Musidorus) knows Pyrocles’ whereabouts, he has no army to defend him should Basilius discover his true sex, making his revelation far more dangerous than the Prince's.

The New Arcadia and The Convent of Pleasure both contain a character who cannot pass as a woman due to his age. Sir Philip Sidney is less explicit about 
Musidorus' inability to pass as female, merely commenting on his age and finding him an alternate means of disguising himself in order to infiltrate his desired partner's secluded home. Margaret Cavendish, on the other hand, is far less subtle: Monsieur TakePleasure, one of the several men hoping to seduce the encloistered Lady Happy, proposes the idea of cross-dressing to his companions as a means of bypassing the Convent's thick walls. His companions dismiss this idea, however, part of the reason being that these men would find it difficult to raise their "voices to a Treble-sound, as for Women to press down their Voices to a Base., ${ }^{, 2}$ The reluctance of Take-Pleasure's companions to crossdress because of their age and inability to modify their voices enough provides the audience with a more concrete explanation of the difficulties surrounding cross-dressing, especially for an older male, where Sidney appears to just assume his audience understands the logic behind Musidorus' choice of disguise (though Pamela residing with the shepherd Dametas and his family does provide some of the reasoning behind this decision).

Given all the “impossibilities” listed by Take-Pleasure’s Adviser and friends, how can the Prince pass himself off as a woman and live with Lady Happy in her Convent? Similar to Pyrocles, the Prince's young age seems to be a factor in his ability to disguise himself as a woman, as a younger man would likely have a voice able to reach the “treble” tones typically considered a woman’s natural range rather than a man’s.

Before Cavendish introduces the Princess as a character in The Convent of Pleasure, some of the female characters who cannot enter the Convent because they are

72. Cavendish, The Convent of Pleasure, Act II Scene 4. 
married talk to Madam Mediator about the Princess who has recently arrived in the convent. Madam Mediator describes her as “a Princely brave Woman truly, of a masculine presence.”73 Despite the description Madam Mediator gives and the Princess dressing as a man to serve and amuse Lady Happy, no one calls the Princess' gender into question, even after she kisses Lady Happy. Given her self-induced isolation in a malefree environment and her determination to remain unmarried, Lady Happy firmly believes that a union with the Princess would be impossible, as they are both women and therefore would never be able to marry, despite the Princess’ masculine features and foreign birth.

Pyrocles and the Prince are twice foreign to the places they try (and ultimately succeed in) infiltrating. Not only are they both from countries other than the ones in which they quest to seduce their respective love interests, but they also dress like women from places where the female population was thought to be more conventionally masculine in appearance. Though Cavendish does not specify the Princess' country of origin, Zelmane poses as an Amazon, “niece to Senicia, queen thereof, lineally descended of the famous Penthesilea slain by the bloody hand of Pyrrhus.”74 Given Madam Mediator's description of the Princess as "a Princely brave Woman truly, of a masculine presence,” one might presume that she claims a similar lineage upon her (offstage) introduction. $^{75}$

73. Cavendish, The Convent of Pleasure, Act II Scene 4.

74. Sidney, The Countess of Pembroke's Arcadia, 145.

75. Cavendish, The Convent of Pleasure, Act II Scene 4. 
Musidorus, upon first encountering Pyrocles in the forests of Arcadia, has some very strong words regarding his cousin's chosen style of dress. Musidorus berates Pyrocles for being "womanish” and, by extension, "weak.” However, rather than cowering from his cousin or being ashamed of himself, Pyrocles provides a rather strong argument in favor of his disguise:

If I be so weak, then can you not with reason stir me up as you did by remembrance of my own virtue; or if indeed I be virtuous, must you confess that love hath his working in a virtuous heart [...] Neither doubt you because I wear a woman's apparel I will be the more womanish, since I assure you, for all my apparel, there is nothing I desire more than fully to prove myself a man in this enterprise. Much might be said in my defense, much more for love, and most of all for that divine creature which hath joined me and love together. ${ }^{76}$

Pyrocles' argument eventually renders Musidorus "as full of care to help his friend as before he was to dissuade him." 77 Pyrocles, like the Prince, does actually "prove” his masculinity by being successful in his suit and seduction of Philoclea, a feat made plausible by his true gender and her status as an unmarried maiden, making their match appropriate for audiences of the time.

Unlike Pyrocles, however, there exists no one inside the Convent who knows (and would therefore recognize) the Prince. As a result, he has no one to truly confide in for the duration of his experience in female garb and must argue his case not against a friend or relative but Mars, the Roman god of war:

What have I on a Petticoat, Oh Mars! thou God of War, pardon my sloth; but yet remember thou art a Lover, and so am I; but you will say, my Kingdom wants me, not only to rule, and govern it, but to defend it: But what is a Kingdom in

76. Sidney, The Countess of Pembroke's Arcadia, 136.

77. Sidney, The Countess of Pembroke's Arcadia, 151. 
comparison to a Beautiful Mistress? Base thoughts flie off, for I will not go; did not only a Kingdom, but the World want me. ${ }^{78}$

The Prince’s short speech is arguably less powerful than Pyrocles’ reasoning, and feasibly a play on the entire discussion between the two cousins, but it still provides a sound argument in favor of the Prince’s supposed transgressions.

Both Zelmane and the Princess dress as men of their own volitions over the course of their respective performances. Zelmane disguises herself as a knight in shoddy armor during Phalantus’ traveling tournament, while the Princess dresses as Lady Happy's male lover/servant during the plays performed within the work. No one calls the genders of Zelmane or the Princess into question, despite both being in their "natural” states. One possible explanation of this phenomenon is the length of Pyrocles and the Prince’s hair while they are in their respective disguised states:

Lyric visions of young boys invariably emphasize their long hair. Michael Drayton's David goes to meet Goliath with 'locks of hayre ... being play'd with by the ayre | Tost to and fro, did with such pleasure move, | As they had been provocatives for love' (711-14). As Raymond Frontain notes, Drayton’s construction of David as a bait to 'allure' Goliath relies more on his hair than his strong arm. [...] The iconic display of a boy with tresses hanging like the golden fleece - in other words, like that precious and female object of male pursuitshould be juxtaposed with the display of a beautiful boy actor. The icon of a naked boy whose hair brushes his shoulders appears and reappears in homoerotic narrative. $^{79}$

This obsession with hair, while not brought up in The Convent of Pleasure, features prominently in The New Arcadia. Musidorus comments extensively on Zelmane’s hair before he realizes that she is really his cousin Pyrocles. Though the Princess' hair

78. Cavendish, The Convent of Pleasure, Act IV Scene 1.

79. Bly, Queer Virgins and Virgin Queans on the Early Modern Stage, 113-14. 
receives no mention in The Convent of Pleasure, neither are the physical features of any of the other characters. She and Lady Happy both have only vague descriptions using terms more often thought of as describing men. This lack of description on Cavendish's part may constitute a play on the phallic puns made by playwrights of the time (and reflected in Sidney's descriptions of Pyrocles in his cross-dressed state), playing on the true gender of the female “onstage.”80

Act III, Scene 1 of The Convent of Pleasure opens with Lady Happy and the Princess sitting together, complimenting each other in an almost absurd fashion and showering one-another with praise. Similarly, when Philoclea first meets Zelmane, the two fawn over each other, the latter going so far as to get to her knees and kiss Philoclea's hand. Unlike the exchange which occurs in The New Arcadia, the wording used by Cavendish implies that the interaction between the Prince(ss) and the object of his/her affections occurs later than the two's first meeting, rather than the second the two encounter one-another. The exchange which takes place in The Convent of Pleasure, while still absurd-sounding, seems far more logical than the one which occurs in The New Arcadia, as Lady Happy and the Princess are not newly acquainted but have known each other for at least a little while before expounding on each other's virtues.

Philoclea and Lady Happy both lament falling in love with someone they think they cannot have, given that, according to societal norms of the time in which these works were written, two women cannot love one-another. In both maidens’ circumstances, the object of their affections assuages these fears. The examples Philoclea

80. Bly, Queer Virgins and Virgin Queans on the Early Modern Stage, 13. 
has of female/female love in the form of Zelmane's love for her and Gynecia's love for Zelmane comfort her. Conversely, the Princess does not comfort Lady Happy until after her lament about love, at which point the Princess enters and assures her that any love between them was harmless:

PRIN. My dearest Mistress, do you shun my Company? is your Servant become an offence to your sight?

L. HAPPY. No, Servant! Your Presence is more acceptable to me then the Presence of our Goddess Nature, for which She, I fear will punish me, for loving you more then I ought to love you.

PRIN. Can Lovers love too much?

L. HAPPY. Yes, if they love not well.

PRIN. Can any Love be more vertuous, innocent and harmless then ours?

L. HAPPY. I hope not.

PRIN. Then let us please our selves, as harmless Lovers use to do.

L. HAPPY. How can harmless Lovers please themselves?

PRIN. Why very well, as, to discourse, imbrace and kiss, so mingle souls together.

L. HAPPY. But innocent Lovers do not use to kiss.

PRIN. Not any act more frequent amongst us Women-kind; nay, it were a sin in friendship, should not we kiss: then let us not prove our selves Reprobates.

They imbrace and kiss, and hold each other in their Arms.

PRIN. These my imbraces though of Femal kind, May be as fervent as a Masculine mind. ${ }^{81}$

81. Cavendish, The Convent of Pleasure, Act IV Scene 1. 
Both girls are upset that they seem to have fallen for someone supposedly impossible for them to desire, and both pray for an alteration to this fate. Philoclea eventually accepts her love for Zelmane, though she first goes through a great deal of internal struggle. Lady Happy, on the other hand, just wants to not be in love. One might read her derision toward the concept of love, especially aimed at someone "unsuitable" to her maidenhood, as echoing Cavendish's views on the unrealistic nature of romances, especially The New Arcadia.

The short plays-within-the-play staged by the convent women in Act III are all about things which might go terribly wrong for married women of any class. Here, it appears as though Margaret Cavendish uses Lady Happy and her fellow Conventdwellers as a medium through which to express her distaste for marriage. However, Cavendish counters these arguments with the Princess' plays in Act IV, both of which end in the marriage between the character played by the Princess (who is dressed as a male in both of these instances) and Lady Happy's. This is not the only place where Cavendish presents opposing views on marriage: in Act II Scene 3, before Madam Mediator approaches Lady Amorous and Lady Vertue to tell them about the Princess in the Convent, the two women discuss how they like being married. While Lady Amorous expresses the opinion one would expect a (non-cross-dressed) female character to have within this play (“I am not so well [in marriage] as I wish I were”), Lady Vertue is quite pleased with her marriage. ${ }^{82}$ Further evidence of Cavendish's conflicted opinion of marriage appears when no one asks Lady Happy if she wishes to marry the Prince once

82. Cavendish, The Convent of Pleasure, Act II Scene 3. 
the ambassador arrives and reveals the Prince's true identity. Instead, the Prince assumes the Lady's willingness to be his bride when he introduces her as “this Fair Lady, who must be your Soveraigness." ${ }^{83}$ While it does say later that Lady Happy and the Prince have “agreed to marry,” confirmation of said agreement from Lady Happy’s lips seems purposefully excluded from the play. ${ }^{84}$

Given the popularity of The New Arcadia during Margaret Cavendish’s lifetime, as well as her propensity for satire, it serves to reason that The Convent of Pleasure not only responds to but parodies Sidney's unfinished final work. This possibility is given further credence in the various parallels between the characters of Pyrocles and the Prince and their interactions with those around them. Both men approach wooing their respective love interests in the same fashion and both make many of the same choices, including dressing as a man while still believed to be a woman. However, the Prince and Lady Happy make choices that are more consistent with Cavendish's opinion that the romances produced by Sidney and others portrayed marriage in an illogical fashion which gave women false impressions thereof. While these choices are not necessarily "logical" or "realistic," especially given Cavendish's reputation for eccentricity, the author portrays them in such a fashion that they might be construed as parodic rather than merely nonsensical. Like Pyrocles' suit of Philoclea, however, and despite the negative portrayals of marriage throughout the play, the Prince's quest for Lady Happy's hand is

83. Cavendish, The Convent of Pleasure, Act II Scene 4.

84. Cavendish, The Convent of Pleasure, Act V Scene 2. 
ultimately successful because it adheres to accepted societal norms regarding gender and social class. 


\section{CONCLUSION}

Identity is an integral part of how an audience perceives the characters in a written work. Disguise on the part of a character, however, can alter this perception. Sir Philip Sidney’s The New Arcadia and Margaret Cavendish’s The Convent of Pleasure both feature cross-dressing as a form of disguise, using it to enable their respective princes to woo their female counterparts. As argued herein, the alteration of physical appearance does not alter one's character. Both protagonists argue in favor of the constancy of their characters, Pyrocles against his cousin Musidorus and the Prince against the god Mars. These two men prove their arguments in favor of character being unaltered by disguise when they succeed in their suits and marry their respective love interests.

Much of the scholarship today regarding Pyrocles and the Prince's cross-dressing focuses on the transgression inherent in the act of cross-dressing itself. However, it is not the gender play engaged in by these characters when they cross-dress that is the transgressive act, though it is certainly controversial in nature. Instead, the cross-dressing on the parts of Sidney and Cavendish's male protagonists constitute a chivalric act aimed at dissolving the true transgression encountered in the story: the "unnatural isolation" of Philoclea and Lady Happy.

Evidence of cross-dressing as chivalric feat can be seen in the character of Zelmane: given her being of the “imperfect sex”, her quest to stay by Pyrocles’ side whilst disguised as the page Daiphantus cannot succeed because Zelmane is not a man. During Sidney’s lifetime, women did not act on stage, even in female roles. Therefore, Zelmane's unsuccessful cross-dressing and the consequences thereof (her sickness and ultimate death) convey a statement that women do not have the ability 
to disguise themselves, especially as men, even for what one might consider a noble purpose. On the other hand, Pyrocles successfully fulfills his quest for Philoclea’s hand without compromising his character or his integrity because of his "maleness."

Pyrocles and the Prince pursue chaste maidens of marriageable age and similar social standing to themselves. Both women are locked away from society, specifically from the supposed trials which arise when women encounter members of the more "perfect” sex. While the isolations of Philoclea and Lady Happy do not occur in the same fashion, both have been sequestered someplace where no man should have the ability to encroach upon her and put her chastity in jeopardy. This constitutes a problem for audiences of the time because women of similar stature to Philoclea and Lady Happy should marry rather than hide away in a forest or convent, whether or not her hiding is of her own volition. A problem such as a sequestered maiden must be remedied at any cost, even if that cost requires actions that are in and of themselves problematic. Therefore, the cross-dressing on the parts of Pyrocles and the Prince functions a means to an end, rather than a true transgression, as it solves the larger problem of the isolation of Philoclea and Lady Happy and is, itself, resolved at the end of the work when the couples join as man and wife.

Both Pyrocles and the Prince argue that their altered physical identities do not change their personalities or ideals. While the audience does not see enough of the Prince outside of his disguised form in The Convent of Pleasure to make a firm argument on behalf of his character, his actions whilst performing as the Princess, especially his argument against the god Mars in Act IV Scene 1, show actions which would likely be seen as adhering to a more "male" personality by an early modern 
audience. Furthermore, the Princess is described as masculine by Madam Mediator, who later (once the Prince reveals his true identity) tells Monsieur Take-Pleasure and his cohort that the kiss she witnessed between Lady Happy and the Prince in his disguised form occurred with more "alacrity" and in a "more Vigorous" fashion than two women should exhibit. Sidney, on the other hand, presents Pyrocles to the audience in his male form several times, both through the stories recounted by various characters and at various points throughout the work. Seeing as the only time anyone accuses the Prince or Pyrocles of being changed by his disguise is when Musidorus first stumbles upon Pyrocles in the forest, it can be reasonably argued that disguise on the parts of these characters did not alter anything other than their physical appearances.

Like Pyrocles, the Prince proves his masculinity by successfully seducing Lady Happy despite his cross-dressed state. However, Cavendish’s telling of his journey shows the author's lack of respect for early modern romances, best exemplified by the character of Lady Happy. By reading the character of Lady Happy as the embodiment of Cavendish's derision for romances such as The New Arcadia and the way these works misrepresent marriage, one might say that Cavendish's problem with The New Arcadia would not have been its gender play but its treatment of women as commodity rather than partner. In her offense at this treatment, she provides sharp satire in The Convent of Pleasure, especially at the expenses of her male characters. At the end of the play, the reader does not come away with a clear sense of whether or not the marriage between the Prince and Lady Happy will be a happy one or if the Lady's words from the beginning of the play will prove true. 
The two princes' female counterparts both wish that the woman to whom they are attracted was really a man so that they might be able to marry, not seeing through their respective disguises until later. Although Zelmane dresses as a knight in order to defend Philoclea’s beauty, Philoclea still fully believes Zelmane’s ruse. Unlike Lady Happy, she accepts her love for Zelmane before finding out that her love is really Prince Pyrocles. When Philoclea does find out, she decides that she will still refer to him as Zelmane, "since in that name [her] love first began." 85 Lady Happy, on the other hand, refuses to let herself accept her love for the Princess until she discovers her true identity, though she does admit her attraction to the woman serving her, despite their differences of opinion regarding the institution of marriage, to which Lady Happy is vehemently against throughout most of the play.

Given the popularity of The New Arcadia during Margaret Cavendish's lifetime, as well as her propensity for satire, it is entirely possible that The Convent of Pleasure is not just a response to, but also a parody of Sidney's unfinished final work, as argued herein. The various parallels between the characters of Pyrocles and the Prince and their interactions with those around them lend further credence to this possibility. The Prince and Lady Happy make choices that are more consistent with Cavendish’s opinion that the romances produced by Sidney and others portrayed marriage in an illogical fashion which gave women false impressions thereof. The author further illustrates this opinion in the plays-within-the-play in Act III of The Convent of Pleasure. While Cavendish’s characters do not make conventionally "logical" choices, she portrays them in such a fashion that they might be construed as parodic rather than merely nonsensical.

85. Sidney, The Countess of Pembroke's Arcadia, 330. 
Pyrocles and the Prince are ultimately successful in their respective plots to seduce and secure the affections of their chosen mates because both of their suits adhere to accepted societal norms of the time. Not only are the matches "good" because they occur between a man and a virtuous (chaste) maiden, both parties are also of a similar social standing, ensuring that, once their respective marriages occur, they fall firmly within the early modern audience's expectations regarding suitable pairings. The New Arcadia contrasts this "good” suit with several nonsensical ones, such as Basilius' suit of Zelmane, which cannot succeed because both parties are male (though Basilius is ignorant of this for the vast majority of the work). Zelmane sidesteps the king's advances several times, clearly uninterested in him and disgusted by his bumbling displays of affection.

Gender play, while not generally accepted in early modern England, can be seen as acceptable as executed by the male characters in The New Arcadia and Convent of Pleasure because of its end result. Pyrocles and the Prince are confident enough in their "maleness" that they remain true to their own characters and goals, while their female counterparts rail against their own desires, almost desperate in their attempts to behave according to the societal expectations belonging to their sex. The character of Zelmane/Daiphantus provides further evidence of this gender discrepancy when her attempt at cross-dressing ends not in a successful suit, but in her death. Also taking into account that women were not allowed on stage until the end of Cavendish's lifetime, it can be reasonably argued that both Sidney and Cavendish are implying that gender play is only moderately acceptable, and only then when it is perpetrated by the more "perfect" 
of the two sexes, as women cannot even act (in England) as members of their own gender, those roles being occupied by boy actors.

According to Mad Madge: The Extraordinary Life of Margaret Cavendish, Duchess of Newcastle, the First Woman to Live by Her Pen, Margaret Cavendish was familiar with romances (such as The New Arcadia) from having read them with her sisters. She condemned these works later in her life for what she saw as unrealistic portrayals of women and marriage, concerned that these works were damaging to the lives of those who read them. Given the popularity of The New Arcadia during Margaret Cavendish’s lifetime, her disdain for romances, her immense respect for William Shakespeare (who was known to draw inspiration from Sir Philip Sidney), and her penchant for satire, it is entirely feasible that The Convent of Pleasure is a retelling of the tale of Prince Pyrocles in parodic form, as argued herein. 


\section{REFERENCES}

“Amazons.” Anthony S. Mercatante and James R. Dow, Ed. The Facts on File Encyclopedia of World Mythology and Legend, Third Edition. New York, NY: Facts on File, Inc., 2009.

Anglin, Sallie. "Material Romance: Embodiment, Environment, and Ecology in Sidney’s New Arcadia.” Sidney Journal, 30.2 (2012).

Bakhtin, Mikhail. Speech Genres and Other Late Essays. Trans. Vern W. McGee. Austin, TX: University of Texas Press, 1986.

Bly, Mary. Queer Virgins and Virgin Queans on the Early Modern Stage. New York, NY: Oxford University Press, 2000.

“burlesque, adj. and n..” OED Online. September 2014. Oxford University Press. http://www.oed.com/view/Entry/24999 (accessed 16 September 2014).

Cavendish, Margaret. The Convent of Pleasure. Ed. Anne Shaver. Baltimore, MD: The Johns Hopkins University Press, 1999.

Greenstadt, Amy. Rape and the Rise of the Author: Gendering Intention in Early Modern England. Burlington, VT: Ashgate Publishing Company, 2009.

Kosofsky Sedgwick, Eve. Between Men: English Literature and Male Homosocial Desire. New York, NY: Columbia University Press, 1985.

Lamb, Mary Ellen. "Exhibiting Class and Displaying the Body in Sidney's The Countess of Pembroke’s Arcadia.” Studies in English Literature, 1500-1900, 37.1 (1997).

Laquer, Thomas. Making Sex: Body and Gender from the Greeks to Freud. Cambridge, MA: Harvard University Press, 1990.

Orgel, Stephen. Impersonations: The Performance of Gender in Shakespeare's England. New York, NY: Cambridge University Press, 1996.

Schleiner, Winfried. "Male Cross-Dressing and Transvestism in Renaissance Romances.” The Sixteenth Century Journal, 19.4 (1988).

Sidney, Sir Philip. The Countess of Pembroke’s Arcadia. New York, NY: Penguin Classics, 1987. 
Stretcowicz, Victor. “Categorizing Redirection in Sidney’s New Arcadia. Narrative Strategies in Early English Fiction. Eds. Wolfgang Gortschacher and Holger Klein. Lewiston, NY and Salzburg, Germany: The Edwin Mellen Press, 1995.

Traub, Valerie. The Renaissance of Lesbianism in Early Modern England. New York, NY: Cambridge University Press, 2002. 